\title{
Combining first- and third-person data in Sports Sciences in France: analysis of an original methodology
}

\author{
Brice Favier-Ambrosini ${ }^{1, *}$ and Matthieu Quidu ${ }^{2,3}$ \\ ${ }^{1}$ Laboratoire Analyse Comparée des Pouvoirs (EA 3350 Université Paris-Est), Groupe de Recherche en Épistémologie, \\ Histoire et Sociologie du sport, Université Paris-Est Marne-La-Vallée, 5, boulevard Descartes, Cité Descartes, \\ Champs-sur-Marne, 77454 Marne-la-Vallée cedex 2, France \\ ${ }^{2}$ Laboratoire d'histoire des sciences et de philosophie (UMR 7117 CNRS-Nancy Université), Nancy, France \\ ${ }^{3}$ Centre de recherche et d'innovation sur le sport (EA 647, Lyon I), Lyon, France
}

Received 3 May 2017, Accepted 12 February 2018

\begin{abstract}
Classically studied from independent methodologies and compartmentalized research programs, first person data (documenting the actor's personal experience from his own standpoint) and third-person data (data produced from the point of view of an outside observer, without reference to what the actor can feel and independently of his own point of view) have been braided together this past decade with a view to access a more complete and complex outlook on actions. How exactly has the field of French Sports Sciences contributed to the propagation of this original methodology consisting in confronting heterogeneous materials? Our epistemological analysis investigates the social and epistemic conditions of its genesis (progressive conquest of diversified subjects, reference to exemplar studies, dissemination from a core group of authors, etc.) until the establishment of an activity close to normal science. It also formalizes the diversity of the methods of joint analysis between these data (correlation, heuristic discordance, etc.) before evaluating the knowledge effects specifically generated (reinforcement of robustness through triangulation, discovery of new regularities, transformation of intervention practices, etc.). Ultimately, combining first and third-person descriptions is an actual example of a genuinely interdisciplinary practice.
\end{abstract}

Keywords: course of in-formation, cognitive anthropology, self-confrontation, epistemology, methodological practices

Résumé - Articuler des données en première et troisième personnes en sciences du sport en France : analyse d'une méthodologie originale. Classiquement étudiées depuis des méthodologies et des programmes de recherche cloisonnés, fonctionnant indépendamment, les données en première personne (documentant l'expérience vécue de l'acteur depuis son propre point de vue) et en troisième personne (données produites depuis le point de vue d'un observateur extérieur, sans référence à ce que l'acteur peut ressentir et indépendamment de son propre point de vue) sont, depuis une décennie, articulées dans l'optique d'accéder à une vision plus globale et complexe des actions. Comment le champ des Sciences du sport français a-t-il contribué à la diffusion de cette méthodologie originale consistant en la confrontation de matériaux hétérogènes? Notre analyse épistémologique examine les conditions, sociales et épistémiques, de sa genèse (conquête progressive d'objets diversifiés, référence à des travaux exemplars, dissémination à partir d'un noyau dur d'auteurs...) jusqu'à l'instauration d'une activité se rapprochant de la science normale. Elle formalise également la diversité des modalités d'articulation entre ces données (corrélation, discordance heuristique...) avant d'évaluer les effets de connaissance spécifiquement générés (renforcement de la robustesse par triangulation, découverte de nouvelles régularités, transformation des pratiques d'intervention...). Au final, l'articulation des points de vue en première et troisième personnes constitue un exemple en acte d'une pratique authentiquement interdisciplinaire.

Mots clés : cours d'in-formation, anthropologie cognitive, auto-confrontation, épistémologie, pratiques méthodologiques

\footnotetext{
*Corresponding author: brice.favier@u-pem.fr
} 


\section{Introduction}

For almost ten years, a set of publications have shared the ambition of braiding together empirical materials of different natures which, following Varela (1996), we shall qualify respectively as first and third-person data. The present epistemological analysis explores the development of this original methodology in the field of French Sports Sciences.

The third-person data represent data produced from the point of view of an outside observer, without reference to what the actor can feel and independently of his own point of view. Are included here measures "not based on the actor's standpoint" (Vermersch, 2010) which can be "captured" or "recorded" like neuro-electric signals, physiological variables or biomechanical parameters. The implementation of this type of data is based either on a necessity, when the subject is unable to verbalize his own experience or when the mechanism under study is $a$ priori considered as non-accessible to consciousness, or on a conviction, when the researcher believes that these indicators are sufficient to reach this goal and the subject's standpoint cannot be considered as reliable.

The same does not apply for so-called first-person data long deemed as "non-scientific" because "too hard to quantify" (Vermersch, 2010, p. 26). These aim at informing on intimate, private, felt, subjective, singular aspects of actions. Here, the interest is focused on what the subject really experiences from his/her own standpoint. The subject is granted the status of "key informer" whether or not he/she is helped by a third party to access his/her own experience ${ }^{1}$. We shall follow Vermersch (2010) when he restricts the meaning of "first-person data" to "explicit descriptions of a reference singular experience associated to a clearly defined action". This way, we shall exclude from this category differential responses (score on a self-assessment scale for instance) as well as verbalization from the subject assessing his own action. These types of information do not actually generate an understanding of the real experience in as much as the subject is requested to position himself in relation to a priori pre-coded categories existing prior to the survey. On the contrary, what is at stake with first-person data inspired by phenomenology is accessing to what is meaningful for the actor, what "appears to him/her without prior refutation of objectivity or extrinsic validity" (Gouju, Vermersch, \& Bouthier, 2003). Hence, all data aiming at understanding the experience of the subjects where the contents of the categories of experience are "to be filled in" by the subject in an open and unspecified way (on the basis of generic categories "empty of content") will thus be considered as first-person data.

\footnotetext{
${ }^{1}$ Here a distinction is made between "radical first-person data" when the actor-informer is not helped by a third party, and "weak first-person (or second-person) data" when the actor's description is mediated by the researcher. Within the framework of the present study, both types of data will be included under the wider name of "first-person data" as, in both cases, it is the standpoint of the actor which is aimed at.
}

In a way, the methodological approach consisting in combining data of a different nature is not radically innovative. As a matter of fact, it is a specific translation of the principle of "triangulation" of data (Van der Maren, 1996): indeed, a result is all the more robust as it can be derived from several independent methods (Wimsatt, Brewer, \& Collins 1981). However, in the last ten years or so, a set of publications in the field of Sports Sciences have tried to go beyond this first level of combining data in order to not only reinforce the validity of the outcome, but also and mainly to access the entire complex dimension of sport performances.

How did this field - which has always studied motor activity from independently developed third and first person standpoints - manage to "braid" these data together? What are the social, epistemic and axiological conditions which made it possible to create and then propagate this original methodology? What are its actual implementation methods? For what differential effects in knowledge?

\section{Method}

The analysis of conditions, modalities and knowledge effects of the method of joint analysis between first- and third-person data consisted to the construct of an empirical corpus in Sports Sciences which is named of "caused occasional corpus" (Quidu, 2011a): "occasional" by opposition to "systematic" because we did not have studied exhaustively the texts from certain journals or certain researchers, but we have chosen only ones which explicitly use the principle of crossing heterogeneous data; "caused" by opposition to "accidental" because the search of texts was intentional. This tracking was operated by building on the bibliography of articles previously analysed (intertextual references networks), through a prolonged scientific watchfulness and a methodical research on various databases in the field of Sports Sciences. The keywords used for databases research (CAIRN, PERSEE, INIST, SPORT'docs Web of Science and Pubmed) were on the one hand: "first person data, phenomenological collection, experiential data collection, data from self-confrontation interviews, data from courses of experience, data from debriefing sessions". On the other hand, the keywords were: "third person data, mechanical data, biomechanical data, physiological measurements". We also used the word "and" for the connection between keywords. In order to circumscribe the field of investigation, we used the keywords: "sport, motor skills, movement, physical education, motor control".

Finally, we formed a corpus composed by around thirty publications in Sports Sciences, from 2001 (date of publication of the princeps article of Roberts) to 2015 (See Appendix) which includes papers from international journals, conference proceedings and thesis manuscripts.

On these corpuses, we applied three epistemological approaches respectively qualified of "comprehensive", "analytic" and "normative" (Quidu, 2011a). 
The first approach identifies the conditions of possibility of the contemporary development of that method. Similar to the work of Quidu (2016) on the appropriation of fractals in Sports Sciences, it's necessary to focus attention on research themes invested by this methodology in order to study the potential expansion of this methodology. Moreover, we try to identify "what are the researchers' profiles?" and "When and how researchers decide to use this kind of method?". Thus, to trace the genesis and the diffusion of an original methodology implies to highlight the "extra-logical factors" (Soler, 2001) that participate in it. These relate to "aesthetic preferences" or themata in the sense of Holton (1981). These orientations are social because they concern the point of view of a whole community of specialists; but they are also subjective because they vary from one individual to another one on the basis of psychological and biographical singularities. In particular, it is necessary to search individual motivations for articulation in order to identify profiles of articulatory researchers.

The second approach is to describe and formalize the logical architecture of the scientific production in order to extract the specific mode of the principle of crossing heterogeneous data. The objective is to encompass, in a typology, all the strategies to combining first- and thirdperson data, until a satisfactory degree of empirical saturation is reached. The various typologies will be constituted on an essentially "ascending" and "inductive" basis, "anchored" on empirical materials (Glaser \& Strauss, 1995). From a confrontation of the multiple isolated efforts to combining data, the formal properties of articulatory strategies have been abstracted in the mode of the ideal type. This twofold operation of abstraction and purification allows a general increase in order to account for a large number of other articulatory attempts. By iteration, a formal typology synthesizing the various modalities is gradually constituted. Such a typology has not been produced in one time: the primitive categories have been modified, eliminated, refined. The final categories were chosen because they provide the best compromise between "predictive power" (descriptive power), "logical purity" (mutual exclusivity), "parsimony" (economy) and "precision" (descriptive finesse). A powerful indicator of the robustness of the typologies finally produced resides in the achievement of an "empirical saturation threshold". The analyses of new isolated cases do not bring any more in terms of sophistication of the categories. The objective of this second approach is to identify the preliminary precautions for joint analysis used by the researchers. Secondly, we try to know if these analyses are conceptually founded or not. Finally, this approach brings out typical forms of results combination of joint analysis.

At last, the third approach tries to identify the differential effects in knowledge induced by this methodology, comparatively to the epistemological contributions generated by papers in which data are analysed separately. Following Lahire (1996) and Berthelot (1990), we consider the epistemic contributions of an approach (at a methodological level) or a program (at a theoretical- ontological level) must be evaluated relatively or more exactly comparatively by comparing them with the results which have been or could have been produced according to another protocol or according to another program. Indeed, for Lahire (1996), it is "scientifically fruitful to take note of the variation of the knowledge effects according to the context adopted": "what are the explanatory gains and losses associated with the transition from an analytical language to an other?". In this case, the question arises as to what is added or changed with the joint analysis in relation to methods or programs which propose a separate, split or juxtaposed study of each category of materials.

These three types of approaches were carried out separately by two independent coders and then confronted with the idea of reinforcing the robustness of the analyses via a triangulation. In the case of divergent readings of the same scientific production, the independent coders confronted their arguments before agreeing on a single interpretation.

Although we took into account some British works, the "geographical area" of our study focuses mainly on the French researchers in Sports Sciences who have published in French and international revues.

The work reported has been approved by ethics committee of the University of Paris-Est-Marne-LaVallée.

\section{Results}

\subsection{Propagation of an original methodology in Sports Sciences: epistemic and social conditions of a genesis}

\subsubsection{What are the objects under study?}

During the past ten years, researchers in Sports Sciences intending to combine first- and third-person materials have progressively gained a whole set of research themes.

\subsubsection{The part of human activity that is pre-reflexive and difficult to verbalize}

The first privileged object was to study the part of human activity which consciousness cannot access as it is pre-reflexive and difficult to verbalize. As such top performances have been especially investigated. They are strongly marked with automatisms which first-person data alone cannot sufficiently document. Then, joining data makes it possible to account for the activity in its complex entirety: the part which can be verbalized and conscious as well as its infra-conscious fringe. This is the case for Gal-Petitfaux, Adé, Poizat and Seifert (2013) and Seifert (2010) in swimming, Roberts et al. (2001) in golf, Mouchet (2012) in rugby, Poizat, Bourbousson, Saury and Sève (2012) and Martinent, Ledos and Nicolas (2014) in table tennis, Saury, Nordez and Sève (2010) in rowing, Bourbousson and Fortes (2012) in basketball, Récopé (2006) in volley-ball. As stated by Gal-Petitfaux et al. (2013, p. 263), "a significant part of the motor actions of high-level athletes is highly automated, to the extent that 
their biomechanical properties are sometimes based on processes not accessible to the actor's pre-reflexive consciousness and not verbalizable by him". These authors suggest an articulation of data in first person - according to the theoretical and methodological framework of the course of action and allowing access to what is significant for the actor in situation - with third-person data "mechanical and biomechanical" in order to take into account non-conscious aspects. Thus, as summarized by Martinent et al. (2014, p. 302.), in order to inform nonverbalizable "incorporated" processes the third-person data complement first-person data from self-confrontation interviews: "However, first-person methodologies seem to be severely limited for the study of the automatic and/or unconscious mechanisms involved in the competitive emotional process. Elements and/or mechanisms of the emotional process not identified by the first-person methodologies could then be updated by an analysis based on third-person methodologies".

\subsubsection{Activities mediated by equipment}

The second study object "privileged" by the jointanalysis approach (Grison \& Riff, 2002) involves activities mediated by equipment or including interaction with a technological device (rowing, swimming with the MADsystem, golf, etc.). This is the case in Saury et al. (2010) in rowing, Gal-Petitfaux et al. (2013) in swimming, Roberts, Jones and Rothberg (2001) in golf, and Poizat, Bourbousson, Saury and Sève (2009) in table tennis. Referring to the work of Roberts et al. (2001) on golf equipment, GalPetitfaux et al. (2013, p.260.) indicate: "These studies have shown the incompleteness of biomechanical data to understand the instrumented activity of high-level athletes, and have stressed the complementary contribution of data on subjective perception that have the athletes". Moreover, "Lippens (2005) argues the understanding of the rowing movement involves to compare the physical data relating to the rowers' behaviour with the corresponding psychological data from the rowers' point of view" (Saury et al., 2010, p.185.).

\subsubsection{The interpersonal communication processes}

Lastly, the interpersonal communication processes have also been researched through joint analysis, especially around two points concerning two directions: The study of emotional communication processes (Martinent et al., 2014; Poizat, 2006; Visioli, 2009) and the study of interpersonal coordination processes (Bourbousson \& Fortes, 2012; Saury et al., 2010; Trohel, 2005).

Regarding the first point the study of emotional communication processes: if emotion is defined as "a form of communication and coordination" (Dumouchel, 1995), it is advisable to be interested in what the actor is feeling as well as in what he/she expresses through his/her body, and then to consider the degree of convergence-divergence between the two. For example, Visioli (2009) studied teaching expertise in Physical Education (P. E.) from the perspective of the dramatization of emotions and thus opposed data stemming from self-confrontation interviews (what does the actor feel?) and from an analysis of nonverbal communication (what does he/she express?).

Regarding the second point the study of interpersonal coordination processes: for example, Bourbousson and Fortes (2012) -discussing at the theoretical level of the joint analysis - studied the dynamics of the development of collective action in basketball. They braided together the theoretical programs of the course of action (firstperson materials which make it possible to appreciate the evolution of the sharing of meaning between players) and of the dynamic approach of non-linear systems (thirdperson materials which make it possible to "identify the stabilisation-destabilisation dynamics of the connections between players").

\subsubsection{What is the profile of researchers using joint analyses?}

These researchers present a typical double profile: a concern for making research functional for actors; and special ontological preferences (Quidu, 2009) around themes like wholeness, unity, paradigmatic plurality, complementarity, complexity and depth.

\subsubsection{A concern for making research functional for actors}

The concern for the practicality of research appears, at a first level, in an ergonomic view of conceiving and improving sports gear. This is the case for authors such as Roberts et al. (2001), Poizat, Haradji and Seifert (2011) or Gal-Petitfaux et al., (2013). Talking about the research he co-signed with Poizat (Poizat et al., 2011), Seifert (2010) indicates that they are analysing "ergonomic issues with a view to help with the conception of material in partnership with Petzl and Simond". At a second level, this concern for practicality is anchored in a will to improve or even create new training devices as with Gal-Petitfaux et al. (2013) whose "study hopes to open up new ways to support the conception of situations of assessment for elite swimmers" (Gal-Petitfaux et al., 2013). This is also the case with Brault (2011) studying the detection of body-swerves in rugby from a biomechanical and perceptual point of view. The author collects materials in first-person from virtual reality situations and data in third-person from biomechanical analyses. Joined analyses are supported by a design aim of training tools. Lastly, at a third level, with many researchers using joint analyses this wish is revealed in the care they take to produce "promising outcomes for an efficient and appropriate intervention" (Mouchet, 2012, p. 246). For example, Mouchet admits he has integrated, from the very beginning of his career as a researcher, "pragmatic concern and perspectives of social utility in the field of PE and arts instruction" (Mouchet, 2012, p. 246). This search of possible benefits for efficient intervention is concretized by "proposing aids to the design of training devices" (Seifert, 2010, p. 105) in the field of sports training 
(Mouchet, 2012; Saury et al., 2010), the P. E. (Récopé, 2006) or the training of teachers (Colin, 2011; Trohel, 2005; Visioli, 2009).

\subsubsection{Ontological preferences}

The profile of researchers using joint analyses is characterized by an acute concern for practicality, but also by remarkable ontological preferences (Quidu, 2009):

\subsection{Sensitivity to totality, wholeness and unity}

combined studies focus on the project of "investigating human activity in its wholeness and unity" (Gal-Petitfaux et al., 2013, p. 278). Seifert (2010, p. 104) acknowledges the fact that "what motivated [his] mixed approach was to have access to an understanding of behaviours which would not be limited to a single perspective". Or, put differently: "The interaction of theoretical frameworks, theoretical objects and/or methodologies is part of a systemic vision in which the whole is larger than the sum of its parts". This is also the case with Berteloot (2008). For whom understanding the perceived effort during a middistance run involves a multiplicity of factors that require different types of data in order to take into account the activity in its totality: "perceived effort is not a simple perception but a construction that is realized in the very course of activity: it is a complex subjective evaluation involving the whole of human activity" (Berteloot, 2008, p. 70).

\subsection{Interest for plurality, complementarity and complexity}

For Gal-Petitfaux et al. (2013, p. 278), "taking into account the various dimensions of the activity of swimmers" enables us to "understand the complexity of the components through which the swimmers organize their performance". The argument is similar with Seifert (2010, p. 99), indicating that his Accreditation to supervise research "is ontologically part of an approach which views human motor functions as a complex system ${ }^{2}$, at the interface between biomechanics, motor control and the dynamic system approach". This inclusive connection to the plurality of the paradigms enables him to "understand the complexity of human motor functions by going beyond a purely mechanical analysis of behaviours". Sharing this interest for dialogue, Mouchet (2012, p. 247) admits to have "empowered the researcher's task with a more general personal way of operating" characterized by "openness, comparison and an interest of complementarity and mutual enrichment".

\subsection{Search for depth}

Récopé (2006, p. 49) mentions the dissatisfaction he felt about his doctoral thesis which was limited to "a

\footnotetext{
${ }^{2}$ Human activity is considered as a "complex system", notably because of the multiplicity and flowing dynamics of the interactions (or couplings) between the elements it combines.
}

descriptive behavioural approach based on what could be observed following the signs of action development", "whereas he would have liked to reveal what people are experiencing, what is meaningful for them, and what knowledge they acquire, immanent to the properties of their actions". Later, the author's interest for documenting the depth of the phenomena led him to cross-reference an intrinsic view - through interview methodologies - and the extrinsic view already in place. In the end, combining first- and third-person materials enables the author to satisfy a search for depth as well as underlying aspects of phenomena.

\subsubsection{What is the way leading to joint analysis?}

There are two typical individual paths leading researchers in Sports Sciences towards joint analysis. First, an author follows a certain methodology (in first or third person) and then perceives limitations which a second type of methodology will rectify. In other words, joint analysis is the end-product of a dissatisfying usage of a single methodology. In some cases, third-person data predates first-person data (Brault, 2011; Récopé, 2006; Seifert, 2010); in other cases, first-person data predates third-person data (Chalabaev, 2006; Martinent et al., 2014; Poizat, 2006; Saury et al., 2010). For instance for Récopé (2006), third-person data preceded first-person data. Indeed, as he was writing his thesis, the author worked at identifying typical motor behaviours in volleyball on the basis of third-person data issued from video analyses. After distinguishing typical motor behaviours related to the dual pattern, he encountered a difficulty in his analysis, in particular when trying to get to the underlying root of these behaviours as these were only inferred from the outside. Récopé then switched to studying sensitivities putting an end to rallying as a basis for the defensive mobilization of sportsmen and women, implying a first-person complementary analysis through interviews ${ }^{3}$.

By contrast, the second path is taken by authors who use joint analysis from the beginning in an attempt to report on the complexity of the phenomena under study; it is a syncretic determination to braid together theoretical frameworks, as in the case of Mouchet (2012). This last author explains that "analysing the scientific research in the field of decision procedures in team sports shows how frustrating it is to use a single model to try and figure out the complexity and subjectivity of decision making. Consequently, we connected several scientific paradigms offering different explanatory models of cognition, thus bringing a special insight into decision making behaviours"

\footnotetext{
${ }^{3}$ Sometimes the same pattern occurs with an opposite order of apparition of the data. For example, during his thesis, Saury (1998) worked in the program of situated cognitive anthropology to study Olympic sailing competitions situations using a first person approach. Then, few years later, the author used the complementary of data in the third person biomechanics type for the study of rowing performance.
} 
(Mouchet, 2012). With this searcher, this outlook is materialized by the conceptualization of an integrative model allowing the combination of rival theoretical frameworks, which eventually leads to the braiding together of both types of data.

\subsection{Typical forms of results' combination}

\subsubsection{What are preliminary precautions for joint analysis?}

The authors using joint analysis, who are part of an innovative approach in Sports Sciences, need to take epistemological precautions and be very careful regarding the combining of data.

\subsubsection{To share fundamental theoretical presuppositions}

First of all, authors like Bourbousson and Fortes (2012) insist on the fact that theoretical frameworks mobilized in joint analysis should share fundamental theoretical presuppositions. Indeed, the authors spotted a "relative similarity in theoretical presuppositions (between the epistemology of situated cognitive anthropology and the dynamical systems theory): enaction heavily borrows from emergence theories and places in its centre the part played by interaction between the individual and his context in the understanding of phenomena" (Bourbousson \& Fortes, 2012, p. 181). Visioli (2009) follows the same direction. For him, combining data from the course of action theory and the "new communication" framework is possible if they "share a set of common theoretical presuppositions" (Visioli, 2009, p. 252). In the same way, Seifert (2010) postulates the construction of "mixed" models" (i.e., combining heterogeneous materials) to understand human activity is possible at the condition they share a minimum common space at three levels: ontological, epistemological and methodological.

\subsubsection{The need for a common study object}

Secondly, Gal-Petitfaux et al. (2013) also specify the need for a common study object: "the crossing of both types of approach is possible inasmuch as they share a same study object: human activity" (Gal-Petitfaux et al., 2013, p. 262). This is also what Bourbousson and Fortes (2012) postulate: for them, one of the reasons "which would make the results obtained within the scope of the course of action research program an interesting candidate to explain the entire mechanisms observed in the dynamic approach of interpersonal coordination resides in the similarity of the research objects: the collective activity as it is unfolding" (Bourbousson \& Fortes, 2012, p. 181).

\subsubsection{Subordination of a theoretical framework over another}

Thirdly, epistemological vigilances are taken at programmatic level. According to some, joint analysis can only be carried out if the subordination of a theoretical framework over another is maintained. Visioli (2009), for example, considers that joint analysis is possible only if primacy of the intrinsic is kept, that is through subordinating the framework of the new communication to the Course of action program. The "extrinsic" data only step in to complete the analysis from the actor's standpoint in order to inform "the constraints and extrinsic effects" of the courses of experience: "It seems to us that it is only under this condition that the studies regarding new communication framework are compatible with a perspective of situated cognition" (Visioli, 2009, p. 157).

\subsubsection{4 "weak epistemological" path}

Following up this vigilance, the respect of a joint analysis going through a "weak epistemological" path in terms of results, without ontological concession concerning the hard core of the research programs, appears as a major epistemological precaution for some researchers using joint analysis like Bourbousson and Fortes (2012, p. 177): "A merging of these two research paths will necessarily take a "weak" epistemological path, likely to join together the results of studies rather than their theoretical aspects". Then, "Through this type of merging, no ontological concession is made by situated cognitive anthropology: the tools of the dynamic system theory are "simply borrowed". Merging credibility is therefore based on the fecundity of the empirical results, not the theoretical ones. The same is true for Martinent et al. (2014, p. 303): "The epistemological articulation between approaches is thus rather weak because it is limited to a merger founded only on the fertility of the empirical results of independent studies".

\subsubsection{How are joint analyses conceptually founded?}

Depending on publications, the confrontation of heterogeneous materials may be theoretically supported (by means of unifying concepts or inclusive models specifically concerned with the issue of joint analysis) or can be operated in an a-theoretical way through juxtaposition of data.

When first-person materials are obtained via selfconfrontation interviews by researchers who are part of the program of situated cognitive anthropology, the crossing of viewpoints is very often theoretically enclosed thanks to the following concepts. The "course of action" which is a theoretical object notably mobilized by Berteloot (2008), Bourbousson and Fortes (2012) or Trohel (2005) and defined by Theureau (2009), "includes the course of experience (i.e., reproducing the dynamics with which players construct meaning following the primacy of the intrinsic) along with the description of the constraints or extrinsic effects weighing on the actor's experience" (Visioli, 2009, p. 179). Secondly the "course of in-formation" starting from the observation that, even though the course of experience makes it possible to apprehend the "characteristics which are meaningful for the actor", it leaves "in the dark other facets of the activity which, though they cannot be shown, told or commented, do play a part in the actor's activity" (Saury et al., 2010, 
p. 22), Theureau (2009) suggests the theoretical object of the "course of in-formation". The latter accounts for the dynamics of structural coupling whether or not the elements involved are meaningful for the actor. The course of in-formation "includes elements connected to the actor's body, situation and culture which do not give cause for experience, but who are still relevant for the internal organization of his activity" (Saury et al., 2010, p. 22). Hence, the description of the course of in-formation goes beyond "the limits of the descriptions of the actor's course of experience inasmuch as some elements which did not give cause to experience can be taken into account". However, it is acceptable "in an enactive perspective only if primacy is given to the course of experience; in other words, it should be founded on a preliminary analysis of the course of experience". This theoretical object is notably mobilized by Saury et al., (2010) and Gal-Petitfaux et al., (2013).

The theoretical objects of the course of action and later of the course of in-formation should be understood as successive developments, within the course of action program with a view to include the diversified dimensions of human activity and structural coupling. While the course of experience is only concerned by the level which is meaningful for the actor, the "surface impact" of the structural coupling, leaving in the dark a large part of processes and phenomena which cannot be made conscious, the course of action integrates the extrinsic effects and constraints. The course of in-formation goes a step further by considering the dimensions that are not meaningful for the actor but which play a part in his/ her cognitive field ${ }^{4}$.

Conversely, other confrontations are made on an a-theoretical mode. This is the case with Récopé (2006), Seifert et al., (2014), Martel (2011), Vanhelst, Béghin, Bui-Xuân and Mikulovic (2012), who, even though noting deep convergences between first- and third-person data do not commit themselves to theorize this joint analysis.

\subsubsection{How are the analyses' outcomes combined?}

Four typical forms of results' combination of joint analysis can be identified in French Sports Sciences. The first three are modes of joint results (congruent correlations; divergences and convergences; heuristics discordances). The last one must be distinguished because it corresponds to a methodological mode of joint analysis (hypotheses testing mode).

\subsubsection{Perfectly congruent correlations}

A first one shows perfectly congruent correlations and actually reinforces the robustness of the results. This is the

\footnotetext{
${ }^{4}$ The joint analysis is also conceptually supported but in a different way by Mouchet (2012) because it represents a consequence of a desire to articulate theoretical frameworks classically presented as opposed (in the field of decision-making processes) in a unifying model.
}

case with Récopé (2006) whose behavioural analyses and explanatory materials converge to identify players sensitive to finalizing. We also observe this figure of crossing in the study of Chalabaev et al. (2009). Such a perfect convergence may lead to cutting the cost of a double methodology. Thus, during a study on junior teachers, Ria (2006) dropped the latter third-person technique (presence of external validation) after noticing a perfect correlation between scores on the self-assessment scale of emotional states and heart rates measures.

\subsubsection{Divergences and convergences}

In other cases, within a single research, divergences and convergences can be found between heterogeneous data (see for example Berteloot, 2008; Mouchet, 2003; Visioli, 2009). This is the case with Visioli (2009) when studying expert teachers in front of their students. He specifically worked at documenting the dialectic between what the body reveals (through third-person data) and what is actually felt by the teachers (first-person data). Thus, the "joint analysis methodology makes it possible to finely document times when (a) the teacher's body betrays him, revealing what he feels to the on looking students; (b) the teacher's body hides his/her feelings by adopting a neutral behaviour; (c) the teacher's "dramatized" body expresses an emotion which does not correspond to his/her feelings; (d) the teacher's body "genuinely" reveals his/or her experience" (Visioli, 2009, p 261). In the end, both types of materials are sometimes in perfect correlation when the teacher's body language genuinely reveals what he/she feels and are divergent when there is a disparity between what is shown and what is actually felt, testifying of the expert teachers' capacity to dramatize their emotions.

\subsubsection{Heuristics discordances}

In a third joint analysis mode which we shall call "heuristics discordances", the two types of data do not converge, which leads to the questioning of some initial hypotheses and the devising of new ones. Studying the perceived exertion with middle-distance runners, Berteloot (2008, p. 69) points out "discrepancies between the objective exertion made (race speed and heart rate) and the perceived exertion". Hence, this challenges the "direct causal link supposed to exist between these two concepts, as stated by Borg's hypotheses". This is how "the heuristic impact of discrepancies" is utilized (Gal-Petitfaux et al., 2013).

\subsubsection{Hypotheses testing mode}

According to the last mode called "hypotheses testing mode", the analysis carried out following a certain methodology reveals a problem which can be explained and solved by several hypotheses being systematically tested by an analysis made with another methodology. Saury et al. (2010) exemplify this mode in their study of 
interpersonal coordination processes in rowing. The firstperson data supplied from the course of experience reveal an unpleasant feeling for one of the women rowers. Then three hypotheses are put forward regarding the motor adjustments of the rower likely to clarify these perceptions. The mechanical analysis finally invalidated one of the hypotheses and helped to confirm the other two. We have to precise the last form is not really a results' combination of joint analysis but more specifically a methodological mode of joint analysis.

\subsection{Differential knowledge effects}

What is the epistemic contribution specifically generated by the efforts in joint analysis? How different or richer is a confrontation of viewpoints compared to research presenting compartmentalized studies?

\subsubsection{The triangulation of data as reinforcement of the robustness of results}

Ria (2006, p. 31) reinforces the solidity of his description of the emotional dynamic of junior teachers by triangulating subjective data (self-evaluation by the subject of the comfortable versus uncomfortable character of his/her experience) and objectifying data (recordings of changes in heart rates). Thus, in the case of an unpleasant period, two simultaneous ${ }^{5}$ recordings can be noted: "a marked acceleration of the heart beat" and "a very negative assessment of the intensity of the feelings". The crossing of the various information collecting techniques on the same event which reinforces their reliability, neutralizing uncertainty (or relativity) due to instruments (Van der Maren, 1996).

\subsubsection{Joint analysis of data as a way of pushing back the intrinsic limitations for each elementary programme}

This $\operatorname{logic}^{6}$ can be found within the framework of cognitive anthropology which develops complementarity links with several alternative programs. For example, Bourbousson and Fortes (2012) show that a collaboration between a Course of action and a dynamic approach in the study of interpersonal coordination makes it possible to push back their respective intrinsic limitations: on the one hand cognitive anthropology, favouring the actor's standpoint, in particular in the framework of the object of the synchronization (ou articulation) of courses of experience, abandons the analysis of the whole activity and can benefit from the dynamic approach which documents the constraints and extrinsic effects of the courses of experience; on the other hand, "because the dynamic approach apprehends the system at a global level of analysis, it is naturally confronted to the necessity of a

\footnotetext{
Bühlmann and Tettamanti (2007) call this a situation of "convergence" of results.

6 Bühlmann and Tettamanti (2007) call this a situation of "complementarity" of approaches.
}

multidisciplinary approach when having to interpret the collective behaviours observed" (p. 180); it can then benefit from the analyses which are "more psychologically oriented" and include the Course of action programme.

Other authors (Colin, 2011; Visioli, 2009) have tried to overcome the difficulty for the course of action to account for the physical, embodied and emotional dimension of the interactions by mobilizing programs specifically oriented towards non-verbal communication (proxemics analysis).

As summed up by Martinent et al., (2014, p. 302), it looks as if first- and third-person approaches are "both apt to explore processes or mechanisms which could not possibly be investigated through another methodology". More specifically, within the framework of the intrinsic dynamic of development of the course of action program, we propose to interpret the formalisation of the theoretical object of the course of in-formation as a test to push back the limitations inherent to the "course of experience" object, with a view to approach the entire complex dimensions of behaviours. The course of experience, being concerned by what is meaningful for the actor, stumbles on the issue of accounting for infra-conscious mechanisms. In the case of Saury et al., (2010, p. 21), it is possible to go beyond this intrinsic limitation by locally summoning mechanical analysis allowing access to "automatisms and subtle behavioural adjustments, non-meaningful for the rowers". It is then possible to confer a "mechanical meaning" to syncretic sensations.

\subsubsection{Joint analysis as a means to discover new regularities}

The comparison of the data in first and third persons also enables the formalization of new regularities, which formalization could not have been achieved without the joint analyses. For Seifert (2010, p. 104), "beyond the contribution of each theoretical framework, their interaction gives rise to new knowledge allowing a typification of human activity". Indeed, for swimmers faced with a device to assess propulsive performances, the author formalizes several "typical activities" according to the speed in consideration. This link between "the speed context and the swimmers' perceptions as to the appropriation of a sports technological device" would "not have been noticed with a mono-disciplinary approach" (Gal-Petitfaux et al., 2013, p. 275). As for Seifert et al. (2014) and Seifert (2010) they observe typical activities diverging between experts and novices in ice climbing from the point of view of the perception of affordances and the variability of coordination patterns. For example, with the inexperienced climber, "the synchronized arm-leg coordination mode, the large number of hammering before the final anchoring and the low degree of self-confidence when anchoring is not very deep lead to a form of typical activity: building reliable support" (Seifert, 2010, p. 114). Conversely, the expert shows greater flexibility - multi-stability - in coordination and an increased perceptive sensitivity to the opportunities offered by the environment. 


\section{Discussion}

In the field of French Sport Sciences, the tendency to braid together heterogeneous empirical materials respectively qualified as first- and third-person data is taking on an original shape, in particular at the instigation of researchers in the Science and Techniques of Sport and Physical Activities engaged in the Course of action (and to a lesser extent in psycho-phenomenology) programme. Concerning sports actions, they empirically operationalize the theoretical objects of the course of in-formation and the course of action (Sève et al., 2013). The declared challenge is to go beyond the limited character of the exclusive consideration of phenomenological descriptions through confronting them with objectifiable objects. The combination of extrinsic and intrinsic standpoints is viewed here as a methodological means serving the end constituted by the theoretical object of the course of information with an aim to access the wholeness and complexity of the actions. It offers a singular, original observatory complementing those already widely operationalized empirically.

The research program of the Course of action should, like any programme, be considered as actual dynamics which, while maintaining intact an irrefutable "hard core" (Lakatos, 1994; Theureau, 2009), successively develop, in its protective belt, unstable analytic and synthetic auxiliary hypotheses or, more precisely, diverse, revisable theoretical objects aiming to the utmost at the epistemic and ontological demands of the hard core and going beyond certain frustrations and dissatisfactions (Sève et al., 2013).

Beyond the intrinsic development dynamics of the Course of action program, other contingent circumstances can explain this interest for the joint analysis of heterogeneous materials. Among these, we may note the singular profile of researchers using joint analysis, the movement for the rehabilitation of the actor's subjectivity and experience as well as the contemporary ${ }^{8}$ symbolic sensitivity to the theme of reconciling opposites (Quidu, 2012a). The genesis of scientific works combining heterogeneous data can also be viewed as the practical actualization of a wider overall movement aiming at joining together the paradigmatic plurality (Quidu, 2012a) and more fundamentally just plurality (Quidu 2012c).

\footnotetext{
${ }^{7}$ Within the framework of the Course of action, human activity is considered as an emerging whole, situated, embodied, autonomous and dynamic; it gives rise to experience; the structural coupling between the actor and his/her world is considered as asymmetrical (Saury et al., 2010; Gal-Petitfaux et al., 2013; Bourbousson and Fortes, 2012).

${ }^{8}$ See Quidu (2012b) regarding the contemporary dispute about the "schizomorpic" diurnal imagination which divides, opposes and disjoints, as opposed to a nocturnal "synthetic" imagination which links things together (Durand, 1968). This could be an actual "semantic basin", that is to say an entire symbolical reorientation affecting a large spectrum of human activities (art, economics, etc.).
}

Whether responding to a contingent general movement or to dynamics intrinsic to the program, the development of studies combining heterogeneous materials is on its way. The present epistemological reflection has analysed the on the spot, in process emergence of an original methodology as it occurs. In the framework of normal science activity as it is being established (Kuhn, 1983), new objects of investigation will progressively be conquered. Among them, we may mention the possibility to study the perceptive strategies of sportspeople through combining a study of their eye movements (third-person data via oculometric techniques objectivising foveol focussing) and of their attention windows (first-person data via clarifying interviews informing peripheral perceptions). Another approach could be envisioned about the various modes of timing, emergent versus event-based (i.e., the temporal management of movements) confronting, on the one hand, fractal analyses of temporal series of tapping (see Lemoine, 2007, for third-person data) and, on the other, an analysis of conscious strategies of temporal regulation and their related feelings (first-person data to be built).

Besides, the theoretical object of the course of information, originally formulated in a speculative way by Theureau and whose first attempts at empiric operationalization concerned sports actions, is not meant to be restricted to the field of Sports sciences ${ }^{9}$. The Course of action program which developed it comes from ergonomics and will thus be liable to apply this new theoretical object to all professional working activities, in fields as varied as artistic creation (musical or choreographic), technological innovation or teaching. In a way, the contributions of Saury, Sève, Seifert, Gal-Petitfaux and their collaborators may be considered as precursory empirical studies liable to supply factual examples to researches tackling other fields of human activity.

Now, if the attempt to braid together heterogeneous data is not limited to the field of Sports sciences, within the framework of cognitive sciences it is not restricted to the Course of action program either. Another research program, neuro-phenomenology (Varela, 1996), shares this requirement. It confronts recordings of the neuroelectrical activity of the brain obtained by imagery techniques (third-person) and psycho-phenomenological accounts of experiences obtained through clarifying interviews (first-person). This was born from a criticism of "eliminativist" models in cognitive sciences (Andrieu, 2007; Quidu, 2011b). As a counterpoint, Varela definitely favoured the "rehabilitation of real-life experience (which requires a disciplined method of access) in the study of cognition" through the concept of enaction

\footnotetext{
${ }^{9}$ The latter has developed a laboratory supporting empirical experimentation on the course of in-formation, in particular because of its institutional structure intrinsically multidisciplinary, as opposed to ergonomics, for example, which are stamped by the monopoly of psychology and consequently less liable to appreciate the constraints and extrinsic effects on the courses of experience (Sève et al., 2012).
} 
postulating the "double meaning of corporeality as a structure which is physical and real, biological and phenomenological".

In the framework of the neuro-phenomenological program, we can find the various modes of joint analysis described above. Indeed, the confrontation of first- and third-person data first allowed the robustness of some results to be reinforced by triangulation. Thus, from a fine description of the dynamic microstructure of real experience as it occurred, Petitmengin (2006) was able to corroborate (or validate) the enactive thesis of a joint apparition of the self and the world, a thesis which had originally been demonstrated through objectifying thirdperson data. Correlations have also been revealed between reports of experience on the one hand and neural synchronisations on the other. Finally, following the example of the Course of action applied to sports motor functioning, neuro-phenomenology is finalized by practical preoccupations and transformative, in this case therapeutic, objectives.

What remains at stake ultimately is keeping at bay any threat of reduction, or even elimination, whether operated from the first-person data pole (it would then be a "mentalist" reduction by phenomenology) or from the third-person data pole (a "materialistic" reduction). For Petitmengin (2005, p. 64), "the discovery of homomorphisms between neuro- and pheno-dynamic structures makes it possible to create bridges between both sides of the gap separating the subjective experience from neurophysiological activity, without however reducing one to the other". As for Bitbol (2006, p. 135), he refuses to see, in the founding work of Varela, the thesis of an "ontological primacy of the real experience" or any re-actualisation of the theory of identity between psychical and neurological processes. Conversely, "what [Varela] points out is how important it may be for science ${ }^{10}$ to have a practice that takes into account the totality of the aspects of an experience, whether subjective or objective". Expressed differently, still according to Bitbol (2006), Varela "does not state a neuro-mental identity, but aims at instituting a close connection between the two investigation modes: neuronal and experiential". In the end, a "fair consciousness science" is more a research strategy to be practised (and Sports sciences notably contributed to this) than a foundationalist ontological statement to be recited; in other words, it is an approach, indeed a methodological position, rather than a theory.

Finally, our epistemological work contains some limitations and complementary studies are required. First of all, our typology of the joint analysis forms concern more specifically the combination of forms of the results than the different ways of conducting joint

\footnotetext{
${ }^{10}$ According to Bitbol (2006), the methodological principle at the core of the neuro-phenomenological approach may be considered as universally pertinent, including in the fields of evolutionary biology and quantic physics.
}

analyses. In other words, we did not classify methodological forms of the joint analysis. In this way, we invite readers to read the work of Bourbousson (2015) which put the focal at this second level of the analysis. Furthermore, complementary studies seem to be necessary to learn more about the social logic identified here by adding other data (socio-demographic for example). Indeed, our study's object is vast and based on papers whose vocation is rarely to discuss the social logic of their production. They also present a simplified argument to respect standards of publication (Holton, 1981). In this way, it could be particularly interesting to conduct interviews with the researchers identified in our work.

\section{Author contribution statement}

All authors contributed equally to the paper.

\section{Appendix: Empirical corpus in Sports Sciences.}

Berteloot, A. (2008). La perception de l'effort chez des coureurs de demi-fond en compétition /The perception of effort by middle-distance runners in competition] (Unpublished master's thesis). University Rennes II, Rennes, France.

Bourbousson, J., \& Fortes, M. (2012). Anthropologie cognitive et théorie des systèmes dynamiques: quelles articulations possibles dans l'analyse de l'activité collective? [Cognitive Anthropology and theory of dynamical systems: what links are possible for the analyses of collective activity?] In M. Quidu (Ed.), Les sciences du sport en mouvement: Innovations et traditions théoriques en STAPS [The Sports Sciences in motion-Theoretical Innovations and traditions in STAPS] (pp. 171-185). Paris, France: L'Harmattan.

Brault S. (2011). La feinte de corps au rugby: déterminants biomécaniques, processus de détection et action de défense [Rugby body feint: biomechanical determinants, detection process and defense action] (Unpublished doctoral dissertation). Université Rennes II, France.

Burns, A.-M. (2013). On the Relevance of Using Virtual Humans for Motor Skills Teaching: A Case Study on Karate Gestures (Unpublished doctoral dissertation). University of Rennes II, Rennes, France.

Chalabaev, A., Major, B., Cury, F., \& Sarrazin, P. (2009). Physiological markers of challenge and threat mediate the effects of performance-based goals on performance. Journal of Experimental Social Psychology, 45/4, 991-994. doi: 10.1016/j.jesp.2009.04.009.

Colin, J. (2011). Analyse de l'intervention d'un enseignant d'EPS auprès d'handicapés mentaux en classe ULIS et en classe de $6^{e}$ [Intervention's analyses of a PE teacher with mental disabilities children in ULIS class] (Unpublished master's thesis). University of Rennes II, Rennes, France. 
Gal-Petitfaux, N., Adé, D., Poizat, G., \& Seifert, L. (2013). L'intégration de données biomécaniques et d'expérience pour comprendre l'activité de nageurs élites et concevoir un dispositif d'évaluation [The integration of biomechanical data and experience to understand the swimmers' activity and design an evaluation system]. Le Travail Humain, 76/3, 257-282. doi: 10.3917/th.763.0257.

Lippens, V. (2005). Inside the rower's mind. In V. Nolte (Ed.), Rowing faster (pp. 185-194). Champaign, USA: Human Kinetic.

Martel, D. (2011). Justesse de la perception d'élèves quant à leur niveau de performance, de discipline et d'effort durant les cours d'éducation physique [Accuracy of students' perceptions of their level of performance, discipline and effort during physical education classes]. Staps, 92, 23-42.

Martinent, G., Ledos, S., \& Nicolas, M. (2014). Méthodologies à la $1^{\text {re }}$ et à la $3^{\mathrm{e}}$ personne. Quelles articulations possibles dans le champ de la psychologie des émotions en contexte compétitif? [Methodologies at the 1st and 3rd persons. What links are possible in the field of psychology of emotions in competitive environment?]. In M. Quidu (Ed.), Les sciences du sport en mouvement: Innovations théoriques en STAPS et implications pratiques en EPS [The Sports Sciences in motion: Theoretical innovations in sport science and practical involvements in PE] (pp. 291-306). Paris, France: L'Harmattan.

Mouchet, A. (2003). Caractérisation de la subjectivité dans les décisions tactiques des joueurs d'élite 1 en rugby /Characterization of subjectivity in the tactical decisions of elite rugby players] (Unpublished doctoral dissertation). University Bordeaux II, Bordeaux, France.

Mouchet, A. (2012). Articulation des modèles scientifiques pour éclairer la complexité des décisions en sport [Combining scientific models to understand the complexity of the sport in decisions]. In M. Quidu (Ed.), Les Sciences du sport en mouvement-Innovations et traditions théoriques en STAPS /The Sports Sciences in motion-Theoretical Innovations and traditions in STAPS] (pp. 243-268). Paris, France: L'Harmattan.

Mouchet, A. (2014). Implications pédagogiques de l'approche psycho-phénoménologique en STAPS [Educational implications of psycho-phenomenological approach in STAPS]. In M. Quidu (Ed.), Les sciences du sport en mouvement: Innovations théoriques en STAPS et implications pratiques en EPS /The Sports Sciences in motion: Theoretical innovations in sport science and practical involvements in PE] (pp. 529-552). Paris, France: L'Harmattan.

Poizat, G. (2006). Analyse en ergonomie cognitive de l'activité collective en tennis de table: contribution à la connaissance des interactions humaines /Cognitive ergonomics analyses of table tennis activity: contribution to human interactions knowledgel (Unpublished doctoral dissertation). University of Rouen, Rouen, France.

Poizat, G., Bourbousson, J., Saury, J., \& Sève, C. (2009). Analyses of contextual information sharing during table tennis matches: An empirical study of coordination in sports. International Journal of Sport and Exercise Psychology, 7/4, 465-487. doi: 10.1080/ 1612197X.2009.9671920.

Poizat, G., Bourbousson, J., Saury, J., \& Sève, C. (2012). Understanding team coordination in doubles table tennis: Joint analyses of first- and third-person data. Psychology of Sport and Exercise, 13/5, 630-639. doi: 10.1016/j.psychsport.2012.03.008.

Poizat, G., Haradji, Y., \& Seifert, L. (2011). Concevoir du matériel sportif à partir d'une approche centrée sur l'activité: une alternative en ergonomie du sport [Design sports equipment with an activity-centred approach: An alternative to sports ergonomics]. Staps, 94/4, 71-83. doi: 10.3917/sta.094.0071.

Poizat, G., Poupommeau, C., Seifert, L., \& Haradji, Y. (2011). Analyser l'activité de glaciéristes pour concevoir des piolets en termes d'appropriation [Analyze the climbers activity to design axes in terms of ownership]. In C. Sève \& G. Poizat (Eds.), Analyse de l'activité et conception en sport /analyses of activity and sport design] (pp. 562-563).Q

Récopé, M. (2006). Normativité et sensibilité: une perspective généalogique d'étude du mouvement et de l'action. Motricité et schèmes des volleyeurs mobilisés en défense /Normativity and Sensitivity: a genealogical perspective study of movement and action. Motor skills and patterns of volleyball players in defensive situation] (Unpublished Habilitation to conduct researches dissertation). University Blaise Pascal, Clermont-Ferrand, France.

Ria, L. (2006). L'entrée dans le métier des enseignants du second degré: un programme de recherche centré sur l'analyse de l'activité [The entry into the profession of secondary school teachers: a research program focused on the analyses of the activity] (Unpublished Habilitation to conduct researches dissertation). University Blaise Pascal, Clermont-Ferrand, France.

Roberts, J.R., Jones, R., \& Rothberg, S.J. (2001). Measurement of contact time in short duration sports ball impacts: an experimental method and correlation with the perceptions of elite golfers. Sports Engineering, 4/4, 191203. doi: 10.1046/j.1460-2687.2001.00084.x.

Roberts, J.R., Jones, R., Rothberg, S.J., Mansfield, N. J., \& Meyer, C. (2006). Influence of sound and vibration from sports impacts on players' perceptions of equipment quality. Proceedings of the Institution of Mechanical Engineers, Part L: Journal of Materials Design and Applications, 220/4, 215-227. doi: 10.1243/ 14644207JMDA86.

Saury, J., Nordez, A., \& Sève, C. (2010). Coordination interindividuelle et performance en aviron : apports d'une analyse conjointe du cours d'expérience des rameurs et de paramètres mécaniques [Interpersonal coordination and performance in rowing: contributions from a joint analyses of rowers' courses of experience and of mechanical parameters]. Activités, 7/2, 2-27. Retrieved from http://www.activites.org/v7n1/v7n1.pdf

Seifert, L. (2010). Coordination motrice et expertise: Pour une approche complexe du contrôle moteur dans les activités physiques et sportives [Motor coordination and 
expertise: For a complex approach of motor control in sport and physical activity] (Unpublished Habilitation to conduct researches dissertation). University of Rouen, Rouen, France.

Seifert, L., Wattebled, L., Herault, R., Poizat, G., Adé, D., Gal-Petitfaux, N., \& Davids, K. (2014). Neurobiological Degeneracy and Affordance Perception Support Functional Intra-Individual Variability of Inter-Limb Coordination during Ice Climbing. PLoS ONE, 9/2. doi: 10.1371/journal.pone.0089865.

Sève, C., Nordez, A., Poizat, G., \& Saury, J. (2013). Performance analyses in sport : contributions from a joint analyses of athletes' experience and biomechanical indicators. Scandinavian Journal of Medicine 83 Science in Sports, 23/5, 576-584. doi: $10.1111 / \mathrm{j} .1600-$ 0838.2011.01421.x.

Trohel, J. (2005). Les interactions tuteur-stagiaire en situation d'entretien de conseil pédagogique au cours de la formation des enseignants d'EPS : articulation des cours d'action et dynamique de la conversation [The tutorstudent interactions in educational counseling interview situation in PE formation: combining courses of action and dynamics of the conversation] (Unpublished doctoral dissertation). University of Rennes II, Rennes, France.

Vanhelst, J., Béghin, L., Bui-Xuân, G., \& Mikulovic, J. (2012). Évaluation de l'activité physique chez l'enfant en surcharge pondérale après un programme de réadaptation: le questionnaire contre l'accélérométrie [Assessment of Physical Activity in obese youth after an intervention program: a comparison between questionnaire and accelerometry measurement]. Staps, 95/1,6773. doi: 10.3917/sta.095.0067.

Visioli, J. (2009). Émotions, Corps et Théâtralité: Contribution à une modélisation de l'expertise quotidienne de l'activité des enseignants en Éducation Physique et Sportive [Emotions, Body and Theatricality: Contribution to modeling the expertise of the daily work of teachers in Physical Education (Unpublished doctoral dissertation). University of Rennes II, Rennes, France.

\section{References}

Andrieu, B. (2008). Devenir hybride [Become a hybrid]. Nancy, France: Presses Universitaires de Nancy.

Berteloot, A. (2008). La perception de l'effort chez des coureurs de demi-fond en compétition /The perception of effort by middle-distance runners in competition/ (Unpublished master's thesis). University Rennes II, Rennes, France.

Berthelot, J.-M. (1990). L'intelligence du social : le pluralisme explicatif en sociologie /The intelligence of social : the explanatory pluralism in sociology]. Paris, France: Presses Universitaires de France.

Bitbol, M. (2006). Une science de la conscience équitable: L'actualité de la neurophénoménologie de Francisco Varela [A science of the fair conscience. News from the neurophenomenology of Francisco Varela]. Intellectica, 43, 135157. Retrieved from http://cat.inist.fr $/$ aModele $=$ affi cheN\&cpsidt $=18334569$.
Bourbousson, J. (2015). La coordination interpersonnelle en sport: Contribution à une approche énactive des couplages sociaux. Note de synthèse d' HDR non publiée. Université de Nantes [Interpersonal Coordination in Sport: Contribution to an Enactive Approach to Social Couplings] (Unpublished Habilitation to conduct researches dissertation). Nantes, France: University of Nantes.

Bourbousson, J., \& Fortes, M. (2012). Anthropologie cognitive et théorie des systèmes dynamiques: quelles articulations possibles dans l'analyse de l'activité collective? [Cognitive Anthropology and theory of dynamical systems: what links are possible for the analyses of collective activity?]. In M. Quidu (Ed.), Les sciences du sport en mouvement: Innovations et traditions théoriques en STAPS /The Sports Sciences in motion-Theoretical Innovations and traditions in STAPS] (pp. 171-185). Paris, France: L'Harmattan.

Brault S. (2011). La feinte de corps au rugby: déterminants biomécaniques, processus de détection et action de défense [Rugby body feint: biomechanical determinants, detection process and defense action/ (Unpublished doctoral dissertation). University of Rennes II, Rennes, France.

Bühlmann, F., \& Tettamanti, M. (2007). Le statut de l'approche qualitative dans des projets de recherche inter disciplinaires [The status of the qualitative approach in interdisciplinary research projects]. Recherche Qualitative, $H S / 3,191-213$. Retrieved from http://www.recherchequa litative.qc.ca.

Chalabaev, A. (2006). L'influence des stéréotypes sexués sur la performance et la motivation en sport et en éducation physique et sportive [The influence of sex stereotypes on participation and performance in sport and PE/(Unpublished doctoral dissertation). Université Joseph-Fourier, Grenoble, France.

Chalabaev, A., Major, B., Cury, F., \& Sarrazin, P. (2009). Physiological markers of challenge and threat mediate the effects of performance-based goals on performance. Journal of Experimental Social Psychology, 45/4, 991-994. doi: 10.1016/ j.jesp.2009.04.009.

Colin, J. (2011). Analyse de l'intervention d'un enseignant d'EPS auprès d'handicapés mentaux en classe ULIS et en classe de $\sigma^{e}$ [Intervention's analyses of a PE teacher with mental disabilities children in ULIS class/ (Unpublished master's thesis). University of Rennes II, Rennes, France.

Dumouchel, P. (1995). Émotions : essai sur le corps et le social [Emotions: essay on the body and the social]. Paris, France: Synthelabo.

Durand, G. (1968). Les structures anthropologiques de l'imaginaire [Anthropological structures of the imaginary]. Paris: Dunod.

Gal-Petitfaux, N., Adé D., Poizat, G., \& Seifert, L. (2013). L'intégration de données biomécaniques et d'expérience pour comprendre l'activité de nageurs élites et concevoir un dispositif d'évaluation [The integration of biomechanical data and experience to understand the swimmers' activity and design an evaluation system]. Le Travail Humain, 76/3, 257-282. doi: 10.3917/th.763.0257.

Glaser, B.G., \& Strauss, A.L. (1995). La production de la théorie à partir des données [The production of theory from data]. Enquête. Archives de La Revue Enquête, 1, 183195.

Gouju, J.-L., Vermersch, P., \& Bouthier, D. (2003). Objectivation des actions athlétiques par entretien d'explicitation. Étude de cas [Objectivation of athletic actions by interview of explicitation. Case study]. Staps, 62/3, 59-73. doi: 10.3917/ sta.062.0059.

Grison, B., \& Riff, J. (2002, June). Validité écologique et situations d'étude privilégiées : de la psychologie expérimentale 
à l'anthropologie cognitive située [Ecological validity and preferred study situations: from the experimental psychology to the situated cognitive anthropology]. Paper presented at the $I V^{e}$ Journées d'étude ACT'ING, Objets théoriques, objets de conception, objets d'analyses et situations d'étude privilégiées, Domaine de Chalès, Sologne, France.

Holton, G. (1981). L'imagination scientifique /The scientific imagination]. Paris, France: Gallimard.

Kuhn, T.S. (1983). La structure des révolutions scientifiques [The Structure of Scientific Revolutions]. Paris, France: Flammarion.

Lahire, B. (1996). La variation des contextes dans les sciences sociales. [The change in social science contexts]. Annales. Histoire, Sciences Sociales, 51/2, 381-407. doi: 10.3406/ ahess.1996.410853.

Lakatos, I. (1994). Histoire et méthodologie des sciences: programmes de recherche et reconstruction rationnelle [History of Science and its Rational Reconstructions] (C. Malamoud \& J.-F. Spitz, Trans.). Paris, France: Presses Universitaires de France.

Lemoine, L. (2007). Implication des processus de timing évènementiels et émergents dans la gestion des aspects temporels du mouvement /Involvement of timing and process event-emerging in the management of temporal aspects of the movement] (Unpublished doctoral dissertation). Université de la Méditerranée, Marseille.

Martinent, G., Ledos, S., \& Nicolas, M. (2014). Méthodologies à la $1^{\text {re }}$ et à la $3^{\mathrm{e}}$ personne. Quelles articulations possibles dans le champ de la psychologie des émotions en contexte compétitif ? [Methodologies at the 1st and 3rd persons. What links are possible in the field of psychology of emotions in competitive environment?]. In M. Quidu (Ed.), Les sciences du sport en mouvement: Innovations théoriques en STAPS et implications pratiques en EPS /The Sports Sciences in motion: Theoretical innovations in sport science and practical involvements in PEJ (pp. 291-306). Paris, France: L'Harmattan.

Mouchet, A. (2003). Caractérisation de la subjectivité dans les décisions tactiques des joueurs d'élite 1 en rugby /Characterization of subjectivity in the tactical decisions of elite rugby players] (Unpublished doctoral dissertation). University Bordeaux II, Bordeaux, France.

Mouchet, A. (2012). Articulation des modèles scientifiques pour éclairer la complexité des décisions en sport [Combining scientific models to understand the complexity of the sport in decisions]. In M. Quidu (Ed.), Les Sciences du sport en mouvement - Innovations et traditions théoriques en STAPS [The Sports Sciences in motion - Theoretical Innovations and traditions in STAPS] (pp. 243-268). Paris, France: L'Harmattan.

Petitmengin, C. (2005). Un exemple de recherche neurophénoménologique: l'anticipation des crises d'épilepsie [An example of neuro-phenomenological research: the anticipation of epileptic seizures]. Intellectica, 40/2, 63-89. Retrieved from http://intellectica.org/SiteArchives.

Petitmengin, C. (2006). L'énaction comme expérience vécue [Enaction as Lived Experience]. Intellectica, 431, 85-92. Retrieved from http://intellectica.org/SiteArchives.

Poizat, G. (2006). Analyse en ergonomie cognitive de l'activité collective en tennis de table: contribution à la connaissance des interactions humaines /Cognitive ergonomics analyses of table tennis activity: contribution to human interactions knowledge (Unpublished doctoral dissertation). University of Rouen, Rouen, France.

Poizat, G., Bourbousson, J., Saury, J., \& Sève, C. (2009). Analyses of contextual information sharing during table tennis matches: An empirical study of coordination in sports.
International Journal of Sport and Exercise Psychology, 7/4, 465-487. doi: 10.1080/1612197X.2009.9671920.

Poizat, G., Haradji, Y., \& Seifert, L. (2011). Concevoir du matériel sportif à partir d'une approche centrée sur l'activité : une alternative en ergonomie du sport [Design sports equipment with an activity-centred approach: An alternative to sports ergonomics]. Staps, 94/4, 71-83. doi: 10.3917/ sta.094.0071.

Poizat, G., Bourbousson, J., Saury, J., \& Sève, C. (2012). Understanding team coordination in doubles table tennis: Joint analyses of first- and third-person data. Psychology of Sport and Exercise, 13/5, 630-639. doi: 10.1016/j.psy chsport.2012.03.008.

Quidu, M. (2009). Les thêmata dans la recherche en STAPS : motivations et modalités d'intervention [The themata in Sports Sciences research: motivations and modalities of intervention]. Staps, 84/2, 7-7. doi: 10.3917/sta.084.0007.

Quidu, M. (2011a). Les STAPS face à la pluralité théorique: approches analytique, normative et compréhensive en Sciences du sport. /The epistemic plurality in Sports Sciences: analytical, normative and understanding approaches]. Sarrebruck: Les Éditions Universitaires Européennes.

Quidu, M. (2011b). L'aventure du corps dans l'épistémologie au $20^{\mathrm{e}}$ siècle [The adventure of the body in epistemology in the 20th century]. In B. Andrieu (Ed.), Le corps du chercheur [The body of the researcher]. Nancy, France: Presses Universitaires de Nancy.

Quidu, M. (2012a). Approches pragmatiques et dispositionnalistes du rapport aux savoirs scientifiques des enseignants d'éducation physique, agrégés et normaliens [Pragmatic and dispositional approaches of the relation to scientific knowledge of physical education teachers]. Revue des Sciences de l'Education, 38/1, 161-186. doi: 10.7202/1016753ar.

Quidu, M. (2012b). Les résonances symboliques des innovations paradigmatiques contemporaines [The symbolic resonances of contemporary paradigmatic innovations]. In M. Quidu (Ed.), Les sciences du sport en mouvement: Innovations et traditions théoriques en STAPS /The Sports Sciences in motion-Theoretical Innovations and traditions in STAPS] (pp. 187-214). Paris, France: L'Harmattan.

Quidu, M. (2012c). Traiter la pluralité en science et en société: quelles homologies? [Process the plurality in science and society: which homologies?]. Paper presented at the Congrès de la Société de philosophie des sciences, Montréal, Montréal, June 1-3, 2012.

Quidu, M. (2016). L'appropriation pluridisciplinaire mais sélective des fractales en STAPS: modalités et effets de connaissance [Multidisciplinary but selective appropriation of fractals in STAPS: modalities and effects of knowledge]. Movement \& Sport Sciences, 94/4, 83-99. doi: 10.1051/sm/ 2016003.

Récopé, M. (2006). Normativité et sensibilité: une perspective généalogique d'étude du mouvement et de l'action. Motricité et schèmes des volleyeurs mobilisés en défense [Normativity and Sensitivity: a genealogical perspective study of movement and action. Motor skills and patterns of volleyball players in defensive situation/ (Unpublished Habilitation to conduct researches dissertation). University Blaise Pascal, ClermontFerrand, France.

Ria, L. (2006). L'entrée dans le métier des enseignants du second degré: un programme de recherche centré sur l'analyse de l'activité /The entry into the profession of secondary school teachers: a research program focused on the analyses of the activity] (Unpublished Habilitation to conduct researches dissertation). University Blaise Pascal, Clermont-Ferrand, France. 
Roberts, J.R., Jones, R., \& Rothberg, S.J. (2001). Measurement of contact time in short duration sports ball impacts: an experimental method and correlation with the perceptions of elite golfers. Sports Engineering, 4/4, 191-203. doi: 10.1046/ j.1460-2687.2001.00084.x.

Saury J. (1998). L'action des entraîneurs dans les situations de compétitions en voile olympique: contribution à une anthropologie cognitive du travail des entraîneurs des sportifs, finalisée par la conception d'aides à l'entraînement. [The action of coaches in Olympic sailing competition situations: contribution to a cognitive anthropology of coaches' work, finalized by the design of training aids] (Unpublished Habilitation to conduct researches dissertation). Université Montpellier 1, Montpellier, France.

Saury, J., Nordez, A., \& Sève, C. (2010). Coordination interindividuelle et performance en aviron : apports d'une analyse conjointe du cours d'expérience des rameurs et de paramètres mécaniques [Interpersonal coordination and performance in rowing: contributions from a joint analyses of rowers' courses of experience and of mechanical parameters]. Activités, 7/2, 2-27. Retrieved from http://www. activites.org/v7n1/v7n1.pdf.

Seifert, L. (2010). Coordination motrice et expertise: Pour une approche complexe du contrôle moteur dans les activités physiques et sportives [Motor coordination and expertise: For a complex approach of motor control in sport and physical activity] (Unpublished Habilitation to conduct researches dissertation). University of Rouen, Rouen, France.

Seifert, L., Wattebled, L., Herault, R., Poizat, G., Adé D., GalPetitfaux, N., \& Davids, K. (2014). Neurobiological Degeneracy and Affordance Perception Support Functional Intra-Individual Variability of Inter-Limb Coordination during Ice Climbing. PLoS ONE, 9/2. doi: 10.1371/journal.pone.0089865.

Sève, C., Theureau, J., Saury, J., \& Haradji, Y. (2012). Drôles d'endroits pour une rencontre: STAPS, Ergonomie \& Cours d'action [Funny places for a meeting: STAPS, Ergonomics and Course of action.]. In M. Quidu (Ed.), Les Sciences du sport en mouvement-Innovations et traditions théoriques en STAPS [The Sports Sciences in motion-Theoretical Innovations and traditions in STAPSJ (pp. 39-64). Paris, France : L'Harmattan.

Sève, C., Nordez, A., Poizat, G., \& Saury, J. (2013). Performance analyses in sport : contributions from a joint analyses of athletes' experience and biomechanical indicators. Scandinavian Journal of Medicine 6 Science in Sports, 23/5, 576-584. doi: 10.1111/j.1600-0838.2011.01421.x.
Soler, L. (2001). Certitudes, incertitudes et enjeux de la philosophie des sciences contemporaine [Certainty, uncertainty and stakes of contemporary philosophy of science]. Le Portique, 7. Retrieved from http://journals.openedition.org/ leportique $/ 236$.

Theureau, J. (2009). Le cours d'action: méthode réfléchie [The course of action thoughtful method]. Toulouse, France: Octarès.

Trohel, J. (2005). Les interactions tuteur-stagiaire en situation d'entretien de conseil pédagogique au cours de la formation des enseignants d'EPS: articulation des cours d'action et dynamique de la conversation /The tutor-student interactions in educational counseling interview situation in PE formation: combining courses of action and dynamics of the conversation] (Unpublished doctoral dissertation). University of Rennes II, Rennes, France.

Van der Maren, J.-M. (1996). La recherche qualitative peut-elle être rigoureuse? [Can be rigorous qualitative research?]. Cahier de Recherche HEC, 96. Retrieved from http:// expertise.hec.ca.

Vanhelst, J., Béghin, L., Bui-Xuân, G., \& Mikulovic, J. (2012). Évaluation de l'activité physique chez l'enfant en surcharge pondérale après un programme de réadaptation : le questionnaire contre l'accélérométrie [Assessment of Physical Activity in obese youth after an intervention program: a comparison between questionnaire and accelerometry measurement]. Staps, 95/1, 67-73. doi: 10.3917/sta.095.0067.

Varela, F.J. (1996). Neurophenomenology: A methodological remedy for the hard problem. Journal of Consciousness Studies, 3/4, 330-349.

Vermersch, P. (2010). Les points de vue en première, seconde et troisième personne dans les trois étapes d'une recherche: conception, réalisation, analyse [The views in the first, second and third persons in the three phases of research: design, implementation, analyses]. Expliciter, 85, 19-32.

Visioli, J. (2009). Émotions, Corps et Théâtralité: Contribution à une modélisation de l'expertise quotidienne de l'activité des enseignants en Éducation Physique et Sportive [Emotions, Body and Theatricality: Contribution to modeling the expertise of the daily work of teachers in Physical Education (Unpublished doctoral dissertation). University of Rennes II, Rennes, France.

Wimsatt, W.C., Brewer, M., \& Collins, B. (1981). Robustness, reliability and overdetermination. In M. Brewer, \& B. Collins (Eds.), Scientific inquiry and the social sciences (pp. 124163). San Francisco: Jossey-Bass Publishers.

Cite this article as: Favier-Ambrosini B \& Quidu M (2018) Combining first- and third-person data in Sports Sciences in France: analysis of an original methodology. Mov Sport Sci/Sci Mot, 100, 39-52 